\title{
Polymerase Chain Reaction: Types, Utilities and Limitations
}

\author{
Patricia Hernández-Rodríguez ${ }^{1}$ and Arlen Gomez Ramirez ${ }^{2}$ \\ ${ }^{1}$ Molecular Biology and Immunogenetics Research Group (BIOMIGEN), \\ Animal Medicine and Reproduction Research Center (CIMRA), \\ Department of Basic Sciences, Biology Program, Universidad de La Salle, Bogotá \\ ${ }^{2}$ Faculty of Agricultural Sciences, Veterinary Medicine Program, Animal Medicine and \\ Reproduction Research Center (CIMRA), Universidad de La Salle, Bogotá
}

Colombia

\section{Introduction}

\subsection{Types, utilities and limitations of PCR}

Nowadays, advances and applications of research in biochemistry and genetic play an important role in the field of health sciences. This has become necessary a molecular approach of the disease for a better interpretation of processes and as horizon in the development of new diagnostic and therapeutic strategies. Therefore, techniques in molecular biology have modified diagnosis, prevention and control of diseases in living beings. Molecular technology has become a crucial tool for identifying new genes with importance in medicine, agriculture, animal production and health, environment and the industry related to these areas. Among the applications of molecular techniques is important to highlight the use of the Polymerase Chain Reaction (PCR) in the identification and characterization of viral, bacterial, parasitic and fungal agents. This technique was developed by Kary Mullis in the mid 80's [1, 2, 3, 4] and since then it has been considered as an essential tool in molecular biology which allows amplification of nucleic acid sequences (DNA and RNA) through repetitive cycles in vitro. The mechanisms involved in this methodology are similar to those occurring in vivo during DNA replication. Each cycle had three temperature patterns carried out by a thermocycler. The first pattern of temperature is $94{ }^{\circ} \mathrm{C}$ (denaturation), the second one is $45-55^{\circ} \mathrm{C}$ (alignment of the specific primers) and the third one is $72^{\circ} \mathrm{C}$ (final extension). The amplification of specific nucleic acid sequences, even in the presence of millions of other DNA molecules, is achieved by thermostable DNA polymerase enzyme (as the name of this technique suggests: "polymerase chain reaction") and specific primers. Primers are short sequences of DNA or RNA (oligonucleotides) that initiate DNA synthesis. These are complementary to the template strand of DNA. The total duration of PCR reaction is around two hours; this depends on the specific conditions of the reaction. Therefore, the DNA polymerase enzyme is capable of producing a complementary strand of a template DNA. In summary, the requirements of PCR are as follows: i. Template DNA; ii. Four deoxyribonucleotides (dNTPs: dATP, dTTP, dGTP and dCTP) which are the 
base material to make the new strand from template DNA; iii. Two primers or oligonucleotides; iv. $\mathrm{Mg}^{2+}$ which joins to nucleotides to be recognized by the polymerase enzyme; and, v. Thermostable DNA polymerase enzyme. The synthesized product in each cycle can serve as a template in the next issue of copies of DNA, creating a chain reaction that can amplify a specific fragment of DNA. Requirements and purpose of PCR are showed in figure 1.

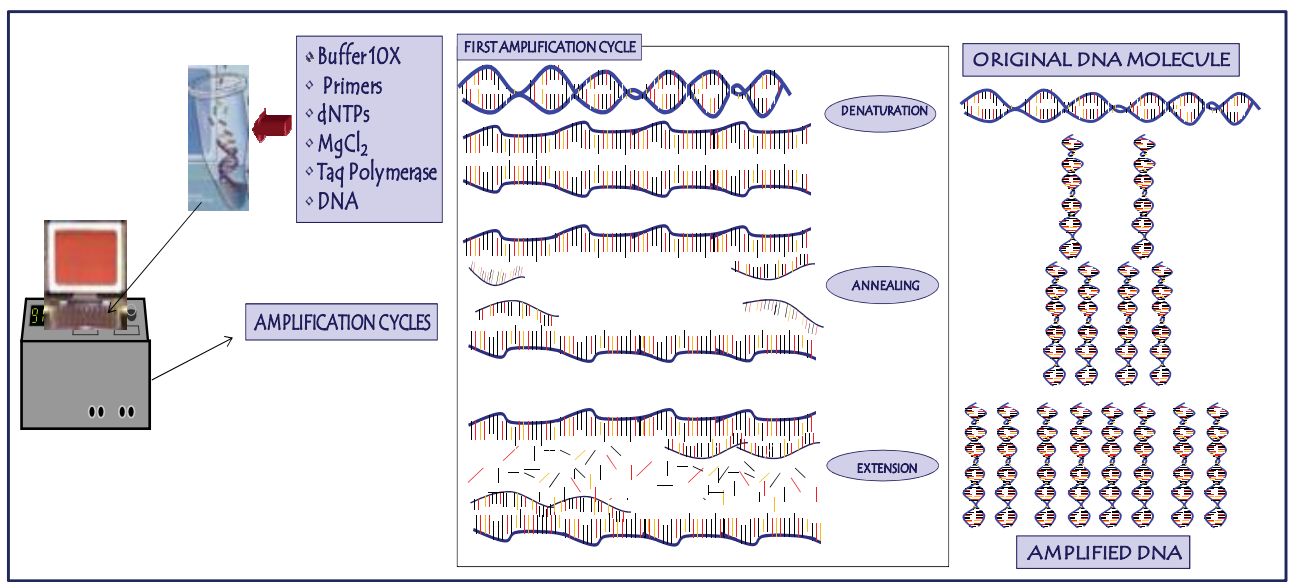

Fig. 1. Requirements and purpose of amplification cycles (denaturation, annealing and extension) in a polymerase chain reaction (PCR).

PCR is a relatively simple technique that can detect a nucleic acid fragment and amplify this sequence. In addition, this technique has other advantages that are described below. This technique offers sensitivity because from small amounts of genetic material can be detected target sequences in a sample. Also this offers specificity due to a specific sequence of DNA is amplified through strict conditions. It is considered a fast technique compared with other methods to detect microorganisms such as bacteria, fungus or virus, which require isolation and culture using culture media or cell lines. Finally we can mention that offers versatility due to the genetic sequences from various microorganisms can be identified with the same reaction conditions for diagnosis of different pathologies $[4,5,6,7]$.

In recent years, modifications or variants have been developed from the basic PCR method to improve performance and specificity, and to achieve the amplification of other molecules of interest in research as RNA. Some of these variants are: i. Multiplex PCR which simultaneously amplified several DNA sequences (usually exonic sequences); ii. Nested PCR increases the specificity of the amplified product for a second PCR with new primers that hybridize within the amplified fragment in the first PCR; iii. Semiquantitative PCR which allows an approximation to the relative amount of nucleic acids present in a sample; iv. RT-PCR which generates amplification of RNA by synthesis of cDNA (DNA complementary to RNA) that is then amplified by PCR; and, v. Real time PCR which performs absolute or relative quantification of nucleic acid copies obtained by PCR. The principles of each of the above techniques are described following. 


\subsection{Multiplex PCR}

Multiplex PCR is an adaptation of PCR which allows simultaneous amplification of many sequences. This technique is used for diagnosis of different diseases in the same sample [8, 9]. Multiplex PCR can detect different pathogens in a single sample [10, 11, 12]. Also it can be used to identify exonic and intronic sequences in specific genes [13] (figure 2) and determination of gene dosage (figure 2, 3 and 4). This is achieved when in a single tube

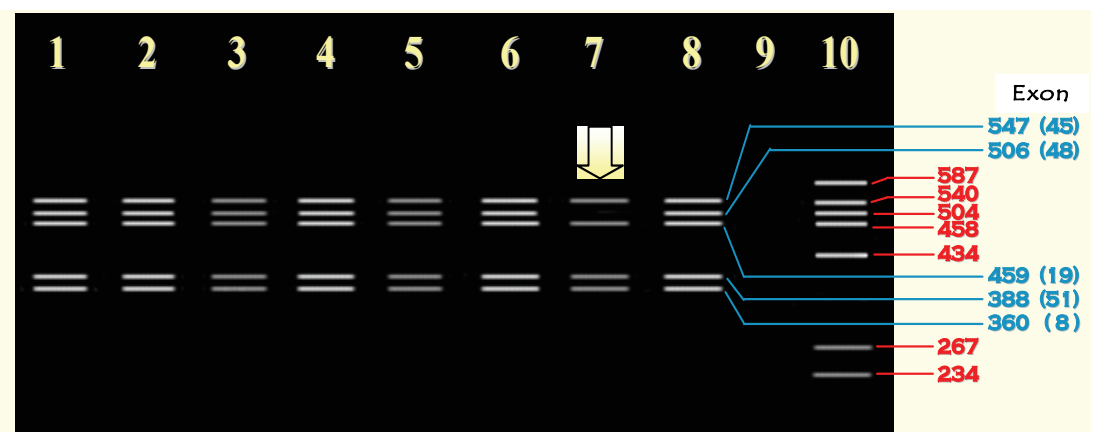

Fig. 2. Results of a multiplex PCR in a patient with Duchenne Muscular Dystrophy.

Dystrophy gene has different mutations in exons; this is the cause of disease. In lane 7 is shown the absence of a band corresponding to exon 48 (506 bp) of the dystrophy gene (Hernández-Rodríguez et al., 2000; Hernández-Rodríguez \& Restrepo, 2002).

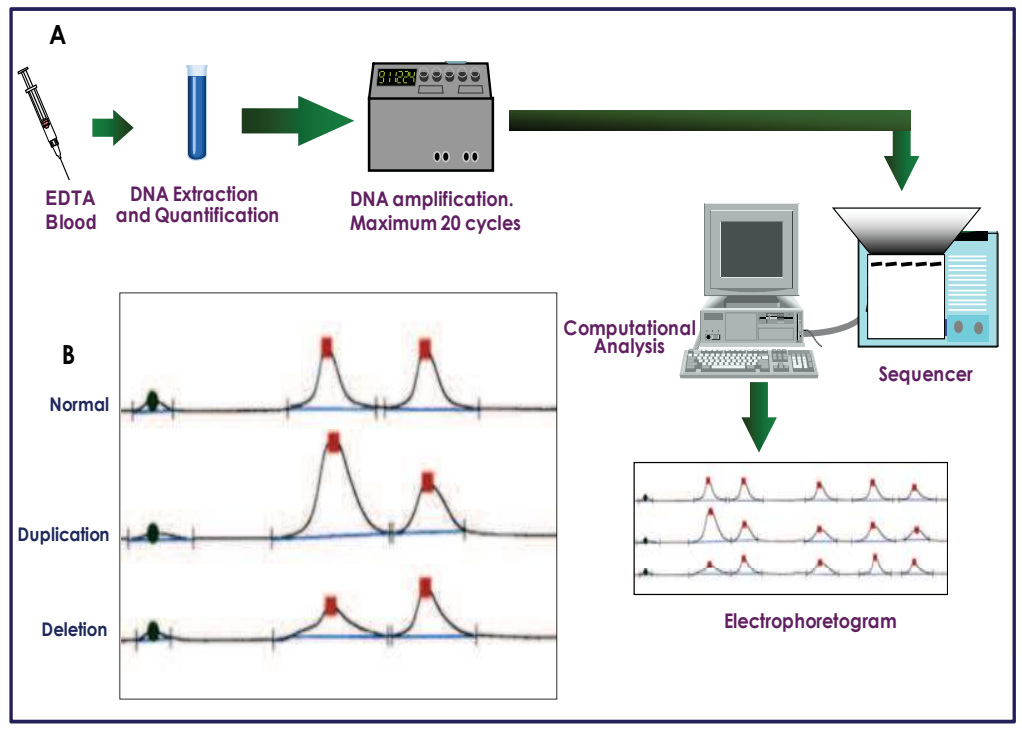

Fig. 3. A: Requirements for multiplex PCR. This molecular method is useful for identification of deletion and duplication mutations. B: Electrophoretogram showing duplication (area under the curve amplified compared to normal) and deletion (area under the curve reduced compared to normal) obtained by analysis of gene dosage. Results are accompanied by a statistical analysis, established by software, which determines areas under curve obtained by a sequencer. 
include sets of specific primers for different targets. In this PCR is important the design of primers because they must be characterized by adherence to specific DNA sequences at similar temperatures. However, it may require several trials to achieve the standardization of the procedure $[8,9]$.

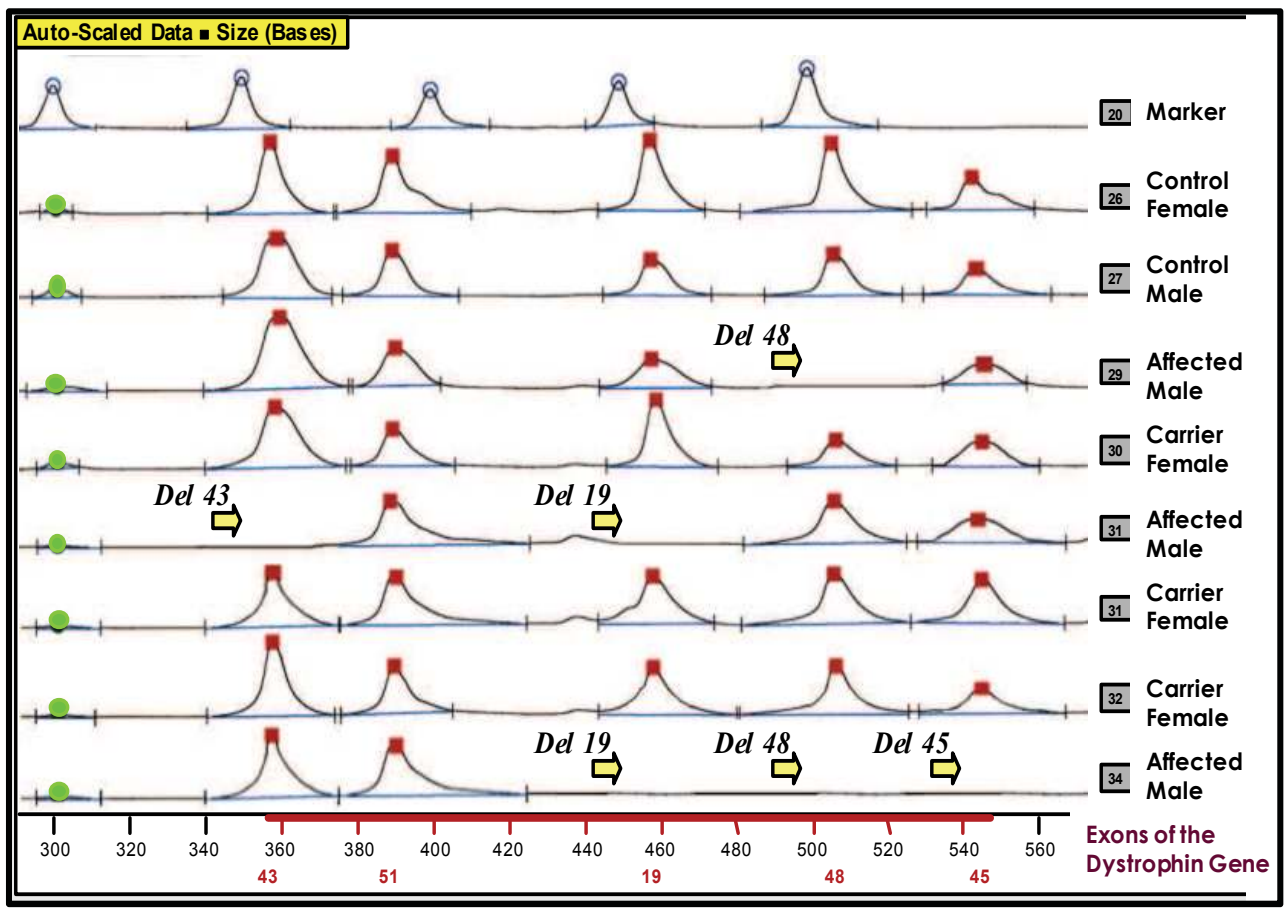

Fig. 4. Electrophoretogram which shows deletions associated with Duchenne Muscular Dystrophy (DMD). In this figure is noted the absence of peaks in men with deletions. Area under the curve in women with DMD is reduced compared to normal control $[13,14]$.

\subsection{Nested PCR}

This PCR increases the sensitivity due to small amounts of the target are detected by using two sets of primers, involving a double process of amplification [15, 16]. The first set of primers allows a first amplification. The product of this PCR is subjected to a second PCR using the second set of primers. These primers used in the second PCR are specific to an internal amplified sequence in the first PCR. Therefore, specificity of the first PCR product is verified with the second one. The disadvantage of this technique is the probability of contamination during transfer from the first amplified product into the tube in which the second amplification will be performed. Contamination can be controlled using primers designed to anneal at different temperatures. Contamination can also be controlled by adding ultra-pure oil to make a physical separation of two mixtures of amplification $[15,17,18]$. 


\subsection{Reverse Transcriptase PCR (RT-PCR)}

This PCR was designed to amplify RNA sequences (especially mRNA) through synthesis of cDNA by reverse transcriptase (RT). Subsequently, this cDNA is amplified using PCR. This type of PCR has been useful for diagnosis of RNA viruses, as well as for evaluation of antimicrobial therapy $[18,19,20,21]$. It has also been used to study gene expression in vitro, due to the obtained cDNA retains the original RNA sequence. The main challenge of using this technique is the sample of mRNA, because this is considered difficult to handle by low level and concentration of mRNA of interest and low stability at room temperature together with sensitivity to action of ribonucleases and $\mathrm{pH}$ change [20, 21, 22].

\subsection{Semiquantitative PCR}

This technique allows an approximation to the relative amount of nucleic acids present in a sample, as mentioned above. cDNA is obtained by RT-PCR when sample is RNA. Then, internal controls (that are used as markers) are amplified. The markers commonly used are Apo A1 and B actin. Amplification product is separated by electrophoresis. Agarose gel is photographed after ethidium bromide staining, and optical density is calculated by a densitometer. The disadvantage of the technique is possibility of nonspecific hybridizations, generating unsatisfactory results. Control of specificity is performed using highly specific probes for hybridization [23, 24] (figure 5).

\subsection{Real time PCR}

Real time PCR or quantitative PCR (qPCR) is other adaptation of the PCR method to quantify the number of copies of nucleic acids during PCR. Thus, qPCR is used to quantify DNA o cDNA, determining gene or transcript numbers present within different samples [25, 26, 27]. qPCR offers advantages such as speed in the result, the reduced risk of contamination and the ease in handling technology [28, 29]. This PCR uses fluorescence detection systems which are generally of two types: intercalating agents and labeled probes with fluorophores.

Intercalating agents such as SYBR Green are fluorochromes that dramatically increase the fluorescence by binding to a double-stranded DNA [30,31,32]. Thus, the increase of DNA in each cycle reflects a proportional increase in the emitted fluorescence. However, it is considered that intercalating agents offer a low specificity because they can be bind to nonspecific products or primer dimers. Several studies have shown that careful selection of primers and using of optimal PCR conditions may minimize this nonspecificity [28, 32, 33]. The use of a high temperature to start the synthesis reaction (hot-start PCR) decreases the risk of nonspecific amplification. Another detection system used in real time PCR are specific hybridization probes labeled with two types of fluorochromes, a donor and an acceptor. The most commonly used probes are hydrolysis or TaqMan probes, molecular beacons probes, and FRET (fluorescent resonance energy transfer) [32, 33, 34]. The increase of DNA in each cycle is proportional to hybridization of probes, which in turn is proportional to the increase in the emitted fluorescence. The use of probes allows identifying polymorphisms and mutations; however, these are more complex and expensive than intercalating agents $[35,36,37]$. 


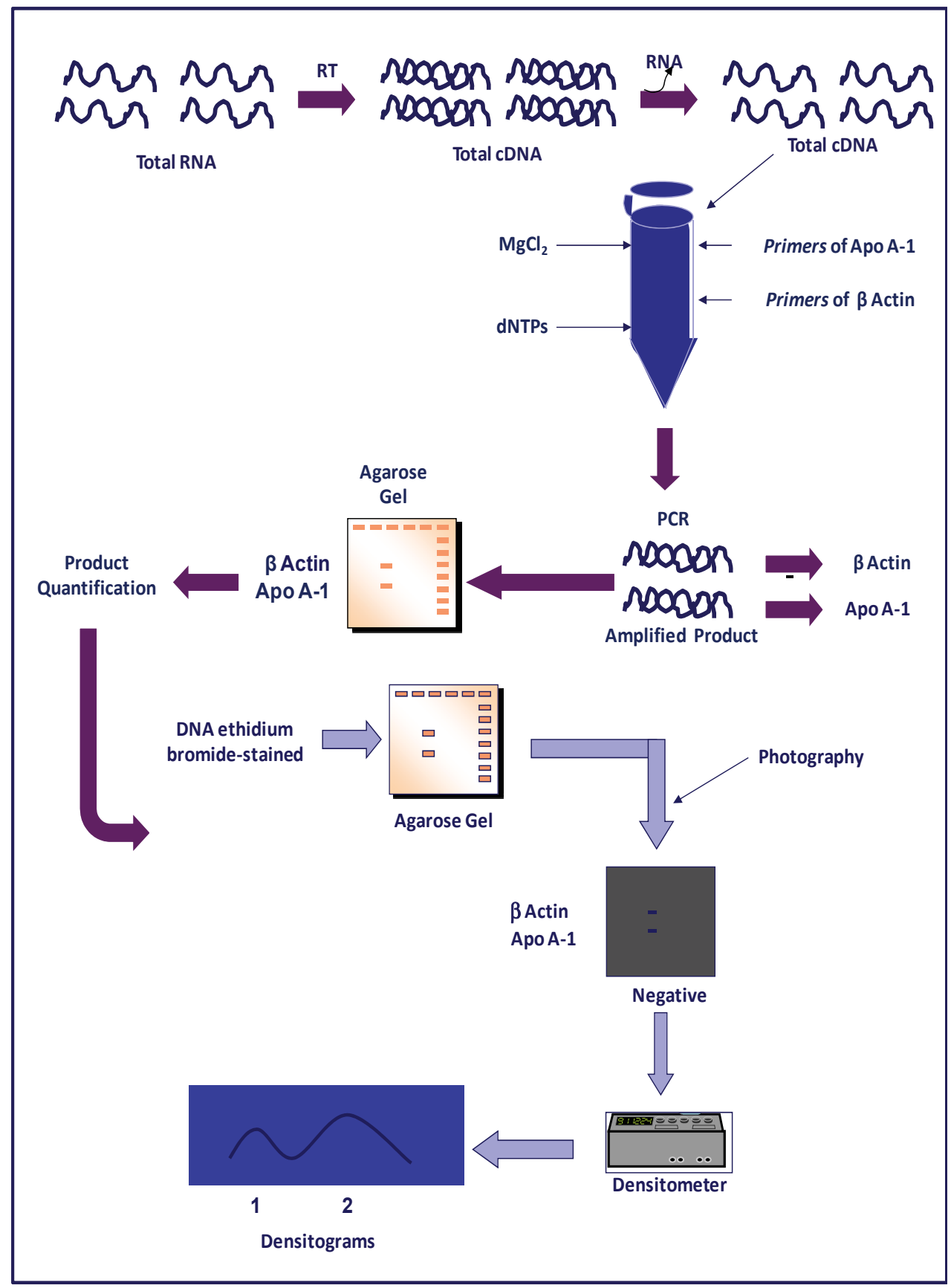

Fig. 5. Semiquantitative PCR procedure. This technique is useful for identifying small amounts of nucleic acids. 


\section{Applications of PCR and impact on science}

During the past 30 years molecular techniques have been under development, however these have had a rapid and tremendous progress in recent year [38]. Among molecular techniques, PCR and its different variations are highlighted as the most commonly used in laboratories and research institutes. Thus, these have contributed to identification and characterization of several organisms and understanding of physiopathology of diverse diseases in human, animal and plant [39, 40]. Also these have provided clues for future research directions in specific topics with impact in public health such as genetics and biochemistry of antimicrobial resistance [41, 42]. The following describes some applications of PCR and its variants in studies in human medicine, forensic sciences, and agricultural science and environment.

\subsection{Medicine}

Molecular biology techniques, particularly PCR, have had a major impact on medicine. The versatility of molecular techniques has allowed advances and changes in all fields of medicine. The following is an overview of the main impacts generated for molecular biology in medical sciences.

Clinical microbiology has been transformed with the use of molecular technology because it has generated a benefit to the patient affected by infectious diseases. Molecular biology has allowed the development of clinical microbiology because it has been possible to identify microorganisms that are difficult to culture, that have many requirements of laboratory or dangerous for laboratory personnel. These problems have been reduced with the implementation of molecular diagnosis that provides high sensitivity, specificity, precision and speed with one small sample. These applications are transforming and complementing the work of biochemists, immunologists, microbiologists and other health professionals who see in the molecular tools new alternatives for a rapid diagnosis of microorganisms as well as for the determination of multiple factors associated with antibiotic resistance thus expanding the knowledge of microbial epidemiology and surveillance at the genetic level $[43,44,45]$.

The usefulness of PCR in identification of microorganisms has led to the selection and quality assurance of blood that blood banks are using for patients with different pathologies [46]. The incorporation of molecular techniques has been of great importance in the identification and characterization of many viruses, including influenza, which through a rapid, sensitive, and effective molecular diagnosis has allowed inclusion of early treatment to benefit patients and control of a high impact infection $[47,48]$.

The implementation of molecular tools has allowed a transformation of pathological studies and has changed the clinical practice. This is how the diagnosis and treatment of complex diseases that require a multidisciplinary clinical team currently has a base of molecular biology due to histopathological evaluation of tissues, which is an important part in the morphological assessment, is insufficient by itself. Thus, the ability to define molecular alterations associated with the disease is increasingly required to clarify the diagnosis and therapeutic guidance [48]. At pathological level, molecular biology has allowed the identification of mutations and carriers of diseases as in diabetes, obesity, neurological, 
muscular, cardiac, metabolic, and congenital diseases and pathologies associated with sensory organs. At the ocular level, implementation of molecular biology has generated enormous advances in knowledge, diagnosis and treatment of ophthalmic diseases [49, 50]. The usefulness of this technique in the identification of mutations associated with ocular diseases has been widely used for the study of families at risk. Several reports show how PCR has allowed expanding the knowledge of certain diseases; thus, Woloschak et al. 1994 [51] showed the loss of heterozygosity in the retinoblastoma gene in pituitary human tumors. It was possible to demonstrate genetic heterogeneity in congenital fibrosis of extraocular muscles. With the advent of molecular technology, it has been possible to understand certain aspects of diseases as in retinitis pigmentosa, microftalmia, retinoblastoma, open-angle glaucoma, ocular diseases due to alterations in mitochondrial DNA and various types of corneal dystrophy, among others [50,52, 53]. Also, genes that cause ocular diseases have been cloned at the anterior and posterior segment. In anterior segment basically aniridia and Peter's anomaly, autosomal dominant diseases in which have been identified candidate genes [54]. In posterior segment, the number of cloned genes has been higher; these are associated with different pathologies described as following. Retinitis pigmentosa with autosomal dominant inheritance pattern in most cases; however, it can also be found in a recessive or digenic form [55]. Congenital Stationary Night Blindness, a disease whose pattern of inheritance is autosomal dominant. Retinoblastoma which the genetic defect affects the retinoblastoma protein $(\mathrm{Rb})$ whose gene $\mathrm{rb}$ has been cloned [56]. Cones degeneration inherited pattern linked to $X$, this means that the disease is transmitted by a carrier mother, where $50 \%$ of boys are likely to get the disease and $50 \%$ of their daughters are likely to pass it. Its alteration affects synthesis of red opsin [57, 58]. Leber hereditary optic neuropathy associated with alteration of mitochondrial DNA whose defect involves activity of mitochondrial enzymes [57]. These findings have strong implications for the understanding of physiopathology of these genetic entities and generate a new concept of ocular clinical practice due to advances in molecular biology not only can classify better the pathology but the diagnosis becomes specific and safe. On the other hand, in those ocular diseases attributed to mutations in genes located on chromosome $X$, it is possible to identify mothers or women on the mother line and to generate secondary prevention measures when inform the carrier or not carrier status of them [49].

Molecular tools have also allowed to perform preimplantation genetic diagnosis (PGD) being used for genetic analysis of embryos before transfer into the uterus. It was first developed in England in 1990, as part of the advances in reproductive medicine, genetics and molecular biology. PGD offers couples at risk of having an affected child the opportunity to have normal child by assisted fertilization. The molecular genetic analysis is performed on one or two blastomeres, and only unaffected embryos are transferred into the uterus. It is important to note that in many countries the using of this reproductive procedure has caused controversy. However, this technique provides an opportunity for couples whose children have shown earlier genetic abnormalities [59, 60, 61].

\subsection{Forensic science}

In forensic pathology, classic morphology remains as a basic procedure to investigate deaths, but recent advances in molecular biology have provided a very useful tool to 
research systemic changes involved in the pathophysiological process of death that cannot be detected by morphology. In addition, genetic basis of diseases with sudden death can also be investigated with molecular methods. Practical application of RNA analysis has not been accepted for post-mortem research, due to rapid decomposition after death. However, recent studies using variants of conventional PCR (qPCR and RT-PCR) have suggested that relative quantification of RNA transcripts can be applied in molecular pathology to research deaths ("molecular autopsy"). In a broad sense, forensic molecular pathology involves application of molecular biology in medical science to investigate the genetic basis of pathophysiology of diseases that lead to death. Therefore, molecular tools support and reinforce the morphological and physiological evidence in research of unexplained death [62].

Molecular methods are used in forensic science to establish the filiations of a person (paternity testing) or to obtain evidence from minimal samples of saliva, semen or other tissue debris [63]. Genetic profile of the alleles identified in different regions of DNA is performed in paternity tests using a genetic marker STR (Short Tandem Repeat). Each region has an allele contributed by mother and one from father. This profile is virtually unique to each individual, offering a high power molecular evidence of genetic discrimination [64, 65].

\subsection{Agricultural sciences and environment}

Applications of molecular techniques in research in agricultural sciences and environment have been very numerous and varied. It is possible that one of the most important contributions of the applications of some molecular techniques such as PCR has been the identification and characterization of multiple infectious agents that have great impact on human and animal health. Some applications in agricultural science and environment research are described below.

Currently, the genome of most domestic animals and major infectious agents that affect animals is known through the use of molecular tools, facilitating the study of mutations associated with disease (http://www.ncbi.nlm.nih.gov/genomes/leuks.cgi). Some of the most recent reports are listed below: i. the identification of polymorphisms in ABCB1 gene in phenobarbital responsive and resistant idiopathic epileptic Border Collies [66]; ii. A mutation of EDA gene associated with anhidrotic ectodermal dysplasia in Holstein cattle [67]; iii. The deletion of Meq gene which significantly decreases immunosuppression in chickens caused by Marek's disease virus [68]; iv. The MTM1 mutation associated with X-linked myotubular myopathy in Labrador Retrievers [69]; v. An insertion mutation in ABCB4 associated with gallbladder mucocele formation in dogs [70]; among others.

Molecular techniques such as conventional PCR or qPCR have also facilitated research in detection of pathogens in plants, animals, and the environment; understanding of their epidemiology; and, development of new diagnostic tests, treatments or vaccines. Conventional PCR or PCR based methods are being applied to identification and characterization of specific pathogens of animals, e.g., infectious bursal disease virus in avian samples [71]; bovine respiratory syncytial virus [72]; Actinobacillus pleuropneumoniae 
from samples of pigs [73]; canine parvovirus type 2 (CPV 2) in faecal samples of dogs [74]; feline leukemia virus (FeLV) and feline immunodeficiency virus (FIV) [75]; among others. Nucleic acid based detection methods are also important to identification of foodborne pathogens, such as Listeria monocytogenes [76]; Campylobacter spp., Salmonella enterica, and Escherichia coli O157:H7 [77].

Despite these important applications of molecular methods, one of the purposes with the greatest impact is the detection and characterization of agents with zoonotic potential, such as pandemic (H1N1) influenza [78]; leptospirosis [39]; Canine visceral leishmaniasis [79]; among others.

In summary, PCR has advantages as a diagnostic tool in conventional microbiology, particularly in the detection of slow growing or difficult to cultivate microorganisms, or under special situations in which conventional methods are expensive or hazardous. Due to the stability of DNA, nucleic acid based detection methods can be also used when inhibitory substances, such as antimicrobials or formalin, are present [80]. Therefore, through the use of molecular techniques has been able to identify different pathogens, to elucidate its epidemiology, to achieve standardization of diagnostic methods, and to establish strategies of prevention and control of diseases, advancing in sanitary regulations in different countries.

\section{Conclusions}

New knowledge has been generated in different fields of science with invention of PCR 25 years ago. The applications of molecular biology have transformed diagnosis, prognosis and treatment of many diseases. Likewise, molecular methodologies to measure and evaluate gene expression have become the key techniques of the post-genomic era. This correlates with the increasing number of reports of molecular technologies to identify and characterize multiple infectious agents and diseases affecting humans, plants, and animals. The above mentioned justifies the establishment of clear regulations and statistical models for evaluation and adoption of these protocols in laboratories of diagnosis [81]. Despite the continuing evolution of molecular biology, future efforts should continue to increase understanding of advantages and disadvantages of molecular methods in diagnosis, and its interpretation within the clinical context. In addition, it is necessary to increase research for the development of guideline for standardization, validation and comparison new molecular diagnostic methods with existing techniques regarding to sample type, sample preparation, PCR amplification, and reporting of results [80]. In conclusion, the development of molecular biology techniques such as PCR and its variants has led to advances in medicine, agriculture, animal science, forensic science and environment, among others; transforming the society and economy, and influencing the quality of life of people and the development of science and countries.

\section{References}

[1] Saiki, RK; Scharf S; Faloona F; Mullis, KB; Horn, GT; Erlich, HA; and Arnheim, N. (1985). Enzymatic amplification of $\beta$-globin genomic sequences and restriction siteanalysis for diagnosis of sickle cell anemia. Science 230: 1350-1354. 
[2] Mullis, K; Faloona, F; Scharf S; Saiki, RK; Horn, GT; Erlich, HA. (1986). Specific enzymatic amplification of DNA in vitro: the polymerase chain reaction. Cold Spring Harbor Symp. Quant. Biol. 51: 263-273.

[3] Mullis, K and Faloona, F. (1987). Specific synthesis of DNA in vitro via a polymerasecatalyzed chain reaction. Methods Enzymol. 155:338-350.

[4] Louie, M; Louie, L; Simor, AE. (2000). The role of DNA amplification of technology in the diagnosis of infection diseases. CMAJ. 163(3): 301-9.

[5] Fredriscks, DN and Relman, DA. (1999). Application polymerase chain reactions to the diagnosis of infectious diseases. Clin. Infect. Dis. 29: 475-88.

[6] Erlich, HA; Gelfand, D; Snisky, JJ. (1991). Recent advances in the polymerase chain reaction. Science. 252: 1643-51.

[7] Tang, YM; Procop, GW; Persong, DH. (1997). Molecular diagnostics of infectious diseases. Clin. Chem. 43: 2021-38.

[8] Jackson, CR; Fedorka-Cray, PJ; Barret, JB. (2004). Use of a Genus and Species Specific Multiplex PCR for amplification of Enterococci. J. Clin Microbiol. 42: 3558-3565.

[9] Toma, C; Lu, Y; Higa, N; Nakasome, N; Chinen, I; Baschkier, A; Rivas, M; Iwanaga, M. (2003). Multiplex PCR Assay for identification of Human Diarrheagenic Eschericha coli. J. Clin. Microbiol. 41: 2669-2671.

[10] Pehler, K; Khanna, M; Water, CR; Henrickson, KJ. (2004). Detection and amplification of human adenovirus species by adenoplex, a multiplex PCR enzyme hybridization assay. J. Clin. Microbiol. 42:4070-4076.

[11] Echeverria, JE; Erdman, DD; Swierkosz, EM; Holloway, BP; Anderson, LJ. (1998). Simultaneous detection and identification of human parainfluenza viruses 1,2 and 3 from clinical samples by multiplex PCR. J. Clin. Microbiol. 36: 1388-91.

[12] Templeton, KE; Scheltinga, SA; Sillekens, P; Crielaard, JW; van Dam, AP; Goenssens, H; Claas, EC. (2003). Development and clinical evaluation of an internally controlled, single tube multiplex Real Time PCR assay for detection of Legionella pneumophila and other Legionella species. J. Clin. Microbiol. 41: 4016-4021.

[13] Hernández-Rodríguez, P; Gómez, Y and Restrepo, CM. (2000). Identification of carries Duchenne and Becker Muscular Dystrophy through gene dosage and DNA polymorphisms. Biomedica. 20 (3): 228-237.

[14] Hernández-Rodríguez, P and Restrepo, CM. (2002). Identification of Deletions in Affected of Duchenne and Becker Muscular Dystrophy (DMD/DMB) and Diagnostic of carrier for Molecular Methodologies. Universitas Scientiarum. 7 (1): 3142.

[15] Jann-Yuan, W; Li-Na, N; Chin-Sheng, C; Chung-Yi, H; Shu-Kuan, W; Hsin-Chih, L; PoRen, H; Kwen-Tay, L. (2004). Performance assessment of a Nested-PCR assay (the RAPID BAP-MTB) and the BD ProbeTec ET system for detection of Micobacterium tuberculosis in clinical specimens. J. Clin. Microbiol. 42: 4599-4603.

[16] Zeaiter, Z; Fournier, PE; Greub, G; Raoult, D. (2003). Diagnosis of Bordertella pertussisand Bordertella parapertussis infections. J. Clin. Microbiol. 41: 919-25.

[17] Kitagawa, Y; Ueda, M; Ando, N; Endo, M; Ishibiki, K; Kobayashi, Y. (1996). Rapid diagnosis of methicillin-resistan Staphylococcus aureus bacteremia by Nested Polymerase Chain Reaction. Ann. Surg. 224: 665-71. 
[18] Jou, NT; Yoshimori, RB; Mason, GR; Louei, JS; Liebling, MR. (2003). Single tube, nested, reverse transcriptase PCR for detection of viable Micobacterium tuberculosis. $J$. Clin. Microbiol. 35: 1161-1165.

[19] Salomon, RN. (1995). Introduction to quantitative reverse transcription polymerase chain reaction. Diag. Mol. Pathol. 4:82-84.

[20] Moon, SH; Lee, YJ; Park, SY; Song, KY; Kong, MH; Kim, JH. (2011). The Combined Effects of Ginkgo Biloba Extracts and Aspirin on Viability of SK-N-MC, Neuroblastoma Cell Line in Hypoxia and Reperfusion Condition. 49(1):13-19.

[21] Li, J; Huang, X; Xie, X; Wang, J; Duan, M. (2011). Human telomerase reverse transcriptase regulates cyclin D1 and G1/S phase transition in laryngeal squamous carcinoma. Acta Otolaryngol. 131(5):546-551.

[22] Puustinen, L; Blazevic, V; Huhti, L; Szakal, ED; Halkosalo, A; Salminen, M; Vesikari, T. (2011). Norovirus genotypes in endemic acute gastroenteritis of infants and children in Finland between 1994 and 2007. . Epidemiol. Infect. 14:1-8.

[23] Wang, J; Zhao, ZH; Luo, SJ; Fan, YB. Expression of osteoclast differentiation factor and intercellular adhesion molecule-1 of bone marrow mesenchymal stem cells enhanced with osteogenic differentiation]. Hua Xi Kou Qiang Yi Xue Za Zhi. 23(3):240-3.

[24] Panitsas, FP and Mouzaki, A (2004). Effect of splenectomy on type-1/type-2 cytokine gene expression in a patient with adult idiopathic thrombocytopenic purpura (ITP). BMC Blood Disord. 4(1):4.

[25] Higuchi, R; Fokler, C; Dollinger, G; Watson, R. (1993). Kinetic PCR analysis Real Time monitoring of DNA amplification reactions. BioTechnology. 11: 1026-30.

[26] Marty, A; Greiner, O; Day, PJR; Gunziger, S; Muhlemann, K; Nadal, D. (2004). Detection Haemophylus influenza Type b by real Time PCR. J. Clin. Microbiol. 42: 3813-3815.

[27] Lobert, S; Hiser, L; Correia, JJ. (2010). Expression profiling of tubulin isotypes and microtubule-interacting proteins using real-time polymerase chain reaction. Methods Cell Biol. 95:47-58.

[28] Mackay, IM; Arden, KE; Nitsche, A. (2002). Real Time PCR in virology. Nucleic Acids Res. 30: 1292-305.

[29] Maibach, RC and Altwegg, M. (2003). Cloning and sequencing an unknown gene of Tropheryma whipplei and deveploment of two LightCycler PCR assay. Diagn. Microbiol. Infect Dis. 46:181-7.

[30] Ke, D; Menard, C; Picard, FJ; Boissinot, M; Ouellette, M; Roy, PH. (2000). Development of conventional and Real Time PCR assays for the rapid detection of group B streptococci. Clin. Chem. 46: 324-31.

[31] Vlková, B; Szemes, T; Minárik, G; Turna, J; Celec P. (2010). Advances in the research of fetal DNA in maternal plasma for noninvasive prenatal diagnostics. Med. Sci. Monit. 16(4):RA85-91.

[32] Moretti, T; Koons, B; Budowle, B. (1998). Enhancement of PCR amplification yield and specificity using AmpliTaq Gold DNA polymerase. Biotechniques. 25: 716-22.

[33] Kellogg, DE; Rybalkin, I; Chen, S; Mukhamedova, N; Vlasic, T. (1994). TaqStart antibody: "hot start" PCR facilitated by a neutralizing monoclonal antibody directed against Taq DNA polymerase. Biotechniques. 16: 1134-7. 
[34] Demeke, T and Jenkins GR (2010). Influence of DNA extraction methods, PCR inhibitors and quantification methods on real-time PCR assay of biotechnologyderived traits. Anal. Bioanal. Chem. 396(6):1977-90.

[35] Chagovetz, A and Blair, S. (2009). Real-time DNA microarrays: reality check. Biochem. Soc. Trans. 37(Pt 2):471-5.

[36] Smith, CJ and Osborn, AM. (2009). Advantages and limitations of quantitative PCR (QPCR)-based approaches in microbial ecology. FEMS Microbiol. Ecol. 67(1):6-20.

[37] Giasuddin, AS; Jhuma, KA; Haq AM. (2008). Applications of free circulating nucleic acids in clinical medicine: recent advances. Bangladesh Med. Res. Counc. Bull. 34(1):26-32.

[38] Fluit, AC; Visser, MR; Schmitz, FJ. (2001). Molecular detection of antimicrobial resistance. Clin. Microbiol. 14(4):836-71.

[39] Hernández-Rodríguez, P; Díaz, C; Dalmau, E; Quintero, G. (2011). A comparison between Polymerase Chain Reaction (PCR) and traditional techniques for the diagnosis of leptospirosis in bovines. Journal of Microbiological Methods. 2011. 84: 1-7.

[40] Gomez, AP; Moreno, MJ; Baldrich, RM; Hernández, A. (2008). Endothelin-1 messenger [corrected] ribonucleic acid expression in pulmonary hypertensive and nonhypertensive chickens. Poult Sci. 87(7):1395-401. Erratum in: Poult Sci. 2008 Aug;87(8):1689.

[41] Sundsfjord, A; Simonsen, GS; Haldorsen, BC; Haaheim, H; Hjelmevoll, SO; Littauer, P; Dahl, KH. (2004). Genetic methods for detection of antimicrobial resistance. APMIS. 112(11-12):815-37.

[42] Courvalin, P and Trieu-Cuot P. Minimizing potential resistance: the molecular view. Clin. Infect. Dis. 2001 Sep 15;33 Suppl 3:S138-46.

[43] Weile, J and Knabbe, C. (2009). Current applications and future trends of molecular diagnostics in clinical bacteriology. Anal. Bioanal. Chem. 394(3):731-42.

[44] Dreier, J; Störmer, M; Kleesiek K. (2007). Real-time polymerase chain reaction in transfusion medicine: applications for detection of bacterial contamination in blood products. Transfus. Med. Rev. 21(3):237-54.

[45] Hutchins, GG and Grabsch, HI. (2009). Molecular pathology the future?. Surgeon. 7(6):366-77.

[46] Dreier J, Störmer M, Kleesiek K. (2007). Real-time polymerase chain reaction in transfusion medicine: applications for detection of bacterial contamination in blood products. Transfus. Med. Rev. 21(3):237-54.

[47] Dale, SE. (2010). The role of rapid antigen testing for influenza in the era of molecular diagnostics. Mol. Diagn. Ther. 2010 Aug 1;14(4):205-14.

[48] Wyczałkowska-Tomasik A, Zegarska J. (2009). Real-time polymerase chain reaction applications in research and clinical molecular diagnostics. Przegl. Lek. 66(4):209-12. 46.

[49] Hernández-Rodríguez, P. (2003). Technical molecular: an advance in the diagnosis and knowledge of ocular pathologies. Journal Science and Technology for Vision and Eye Health. 1(1): 113-122. 47.

[50] Mahdy MA.(2010a). Gene therapy in glaucoma-part 2: Genetic etiology and gene mapping. Oman J. Ophthalmol. 3(2):51-9. 48.

[51] Woloschak, M; Roberts, J; and Kalmon, D. (1994). Loos of heterozygosity at the retinoblastoma locus in human pituitary tumors. Cancer. 74(2): 693-96. 49. 
[52] Mahdy MA. (2010b). Gene therapy in glaucoma-3: Therapeutic approaches. Oman J. Ophthalmol. 3(3):109-16. 50.

[53] Traboulsi, E; Bjorn, A; Lee, AB;, Khamis, AR and Engle, E. (2000). Evidence of genetic heterogeneity in autosomal recessive congenital fibrosis of the extraocular muscles. American journal of Ophthalmology. 129(5): 658-662. 51.

[54] Jordan, T; Hanson, Y and Zaletayev, D. (1992). The human PAX6 gene is mutated in two patients with aniridia. Nat. Genet. 1: 328-32.52.

[55] Farrar, GJ; Kenna, PF and Humphries, P. (2002). On the genetics of retinitis pigmentosa and on mutation independent approaches to therapeutic intervention. EMBO J. 21[5]: 857-64. 53.

[56] Bogdanici, C; Miron, I and Gherghel, D. (2000). Actualities in retinoblastoma's treatment. Ophthalmology. 50(4): 48-54. 54.

[57] Serratrice, J; Desnuelle, C ; Granel, B ; De Roux-Serratrice, C and Weiller, P. (2001). Mitochondrial diseases in adults. Rev. Med. Interne. 22 suppl $3: 356-6655$.

[58] McLaughing, ME; Lin, D; Berson, EL and Dryja, TP. (1993). Recessive mutations in the gene encoding the beta subunit of rod phosphodiesterase in patients with retinitis pigmentosa. Nat. Genet. 4: 130-34. 56.

[59] Giasuddin, AS; Jhuma, KA; Haq, AM. (2008). Applications of free circulating nucleic acids in clinical medicine: recent advances. Bangladesh Med. Res. Counc. Bull. 34(1):26-32. 57.

[60] Basille, C; Frydman, R; El Aly, A; Hesters, L; Fanchin, R; Tachdjian, G; Steffann, J; LeLorc'h, M; Achour-Frydman, N. (2009). Preimplantation genetic diagnosis: state of the art. Eur. J. Obstet. Gynecol. Reprod. Biol. 145(1):9-13. 58.

[61] Vlková, B; Szemes, T; Minárik, G; Turna, J; Celec, P. (2010). Advances in the research of fetal DNA in maternal plasma for noninvasive prenatal diagnostics. Med. Sci. Monit. 1;16(4):RA85-91. 59.

[62] Maeda, H; Zhu, BL; Ishikawa, T; Michiue, T. (2010). Forensic molecular pathology of violent deaths. Forensic. Sci. Int. 203(1-3):83-92. 60.

[63] Butler, JM. Forensic DNA Typing: Biology, Technology, and Genetics of STR. 1 Edition. NY. Academic Press (2005). 61.

[64] Liu P, Li X, Greenspoon SA, Scherer JR, Mathies RA.. (2011). Integrated DNA purification, PCR, sample cleanup, and capillary electrophoresis microchip for forensic human identification. Lab. Chip. 21;11(6):1041-8. 62.

[65] Hurth C, Smith SD, Nordquist AR, Lenigk R, Duane B, Nguyen D, Surve A, Hopwood AJ, Estes MD, Yang J, Cai Z, Chen X, Lee-Edghill JG, Moran N, Elliott K, Tully G, Zenhausern F. (2010). An automated instrument for human STR identification: design, characterization, and experimental validation. Electrophoresis. 31(21):35103517. 63.

[66] Alves, L; Hülsmeyer, V; Jaggy, A; Fischer, A; Leeb, T; Drögemüller M. (2011). Polymorphisms in the ABCB1 Gene in Phenobarbital Responsive and Resistant Idiopathic Epileptic Border Collies. J. Vet. Intern. Med. doi: 10.1111/j.19391676.2011.0718.x. [Epub ahead of print]. 64.

[67] Ogino, A; Kohama, N; Ishikawa, S; Tomita, K; Nonaka, S; Shimizu, K; Tanabe, Y; Okawa, H; Morita, M. (2011). A novel mutation of the bovine EDA gene associated with anhidrotic ectodermal dysplasia in Holstein cattle. Hereditas. 148(1):46-9. 65. 
[68] Li, Y; Sun, A; Su, S; Zhao, P; Cui, Z; Zhu, H. (2011). Deletion of the Meq gene significantly decreases immunosuppression in chickens caused by pathogenic Marek's disease virus. Virol. J. 8:2. 66.

[69] Beggs, AH; Böhm, J; Snead, E; Kozlowski, M; Maurer, M; Minor, K; Childers, MK; Taylor, SM; Hitte, C; Mickelson, JR; Guo, LT; Mizisin, AP; Buj-Bello, A; Tiret, L; Laporte, J; Shelton, GD. (2010). MTM1 mutation associated with X-linked myotubular myopathy in Labrador Retrievers. Proc. Natl. Acad. Sci. 107(33):14697702. 67.

[70] Mealey, KL; Minch, JD; White, SN; Snekvik, KR; Mattoon, JS. (2010). An insertion mutation in ABCB4 is associated with gallbladder mucocele formation in dogs. Comp. Hepatol. 9:6. 68.

[71] Cardoso, TC; Rosa, AC; Astolphi, RD; Vincente, RM; Novais, JB; Hirata, KY; Luvizotto, MC. (2008). Direct detection of infectious bursal disease virus from clinical samples by in situ reverse transcriptase-linked polymerase chain reaction. Avian. Pathol. 37(4):457-61. 69.

[72] Hakhverdyan, M; Hägglund, S; Larsen, LE; Belák, S. (2005). Evaluation of a single-tube fluorogenic RT-PCR assay for detection of bovine respiratory syncytial virus in clinical samples. J. Virol. Methods. 123(2):195-202.70.

[73] Savoye, C; Jobert, JL; Berthelot-Hérault, F; Keribin, AM; Cariolet, R; Morvan, H; Madec, F; Kobisch, M. (2000). A PCR assay used to study aerosol transmission of Actinobacillus pleuropneumoniae from samples of live pigs under experimental conditions. Vet. Microbiol. 73(4):337-47. 71.

[74] Kumar, M and Nandi, S. (2010). Development of a SYBR Green based real-time PCR assay for detection and quantitation of canine parvovirus in faecal samples. J. Virol. Methods. 169(1):198-201. 72.

[75] Arjona, A; Barquero, N; Doménech, A; Tejerizo, G; Collado, VM; Toural, C; Martín, D; Gomez-Lucia, E. (2006). Evaluation of a novel nested PCR for the routine diagnosis of feline leukemia virus (FeLV) and feline immunodeficiency virus (FIV). J. Feline Med. Surg. 9(1):14-22. 73

[76] Leclercq, A; Chenal-Francisque, V; Dieye, H; Cantinelli, T; Drali, R; Brisse, S; Lecuit, M. (2011). Characterization of the novel Listeria monocytogenes PCR serogrouping profile IVb-v1. Int. J. Food Microbiol. Mar 21. [Epub ahead of print]. 74.

[77] Jokinen, C; Edge, TA; Ho, S; Koning, W; Laing, C; Mauro, W; Medeiros, D; Miller, J; Robertson, W; Taboada, E; Thomas, JE; Topp, E; Ziebell, K; Gannon, VP. (2011). Molecular subtypes of Campylobacter spp., Salmonella enterica, and Escherichia coli O157:H7 isolated from faecal and surface water samples in the Oldman River watershed, Alberta, Canada. Water Res. 45(3):1247-57. 75.

[78] Slomka, MJ; Densham, AL; Coward, VJ; Essen, S; Brookes, SM; Irvine, RM; Spackman, E; Ridgeon, J; Gardner, R; Hanna, A; Suarez, DL; Brown, IH. (2009). Real time reverse transcription (RRT)-polymerase chain reaction (PCR) methods for detection of pandemic (H1N1) 2009 influenza virus and European swine influenza A virus infections in pigs. Influenza Other Respi Viruses. 4(5):277-93. 76.

[79] Travi, BL; Tabares, CJ; Cadena, H; Ferro, C; Osorio, Y. (2001). Canine visceral leishmaniasis in Colombia: relationship between clinical and parasitologic status and infectivity for sand flies. Am. J. Trop. Med. Hyg. 64(3-4):119-24. 77. 
[80] Pusterla, N; Madigan, JE; Leutenegger, CM. (2006). Real-time polymerase chain reaction: a novel molecular diagnostic tool for equine infectious diseases. J. Vet. Intern. Med. 20(1):3-12. 78.

[81] Niedrig, M; Schmitz, H; Becker, S; Günter, S; Meulen, J; Meter, H; Ellerbrok, H; Nitsche, A; Gelderblom, HR; Drosten, C. (2004). First international quality assurance study on the rapid detection of viral agents of bioterrorism. J. Clin. Microbiol. 42: 1753-5. 79. 


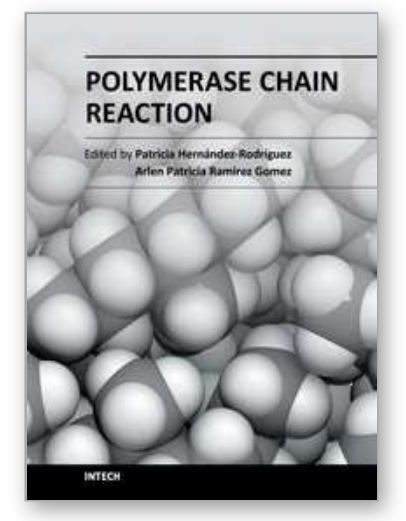

\author{
Polymerase Chain Reaction \\ Edited by Dr Patricia Hernandez-Rodriguez
}

ISBN 978-953-51-0612-8

Hard cover, 566 pages

Publisher InTech

Published online 30, May, 2012

Published in print edition May, 2012

This book is intended to present current concepts in molecular biology with the emphasis on the application to animal, plant and human pathology, in various aspects such as etiology, diagnosis, prognosis, treatment and prevention of diseases as well as the use of these methodologies in understanding the pathophysiology of various diseases that affect living beings.

\title{
How to reference
}

In order to correctly reference this scholarly work, feel free to copy and paste the following:

Jennifer E. Hardingham, Ann Chua, Joseph W. Wrin, Aravind Shivasami, Irene Kanter, Niall C. Tebbutt and Timothy J. Price (2012). BRAF V600E Mutation Detection Using High Resolution Probe Melting Analysis, Polymerase Chain Reaction, Dr Patricia Hernandez-Rodriguez (Ed.), ISBN: 978-953-51-0612-8, InTech, Available from: http://www.intechopen.com/books/polymerase-chain-reaction/braf-v600e-mutation-detectionusing-high-resolution-probe-melting-analysis

\section{INTECH}

open science | open minds

\author{
InTech Europe \\ University Campus STeP Ri \\ Slavka Krautzeka 83/A \\ 51000 Rijeka, Croatia \\ Phone: +385 (51) 770447 \\ Fax: +385 (51) 686166 \\ www.intechopen.com
}

\author{
InTech China \\ Unit 405, Office Block, Hotel Equatorial Shanghai \\ No.65, Yan An Road (West), Shanghai, 200040, China \\ 中国上海市延安西路65号上海国际贵都大饭店办公楼 405 单元 \\ Phone: +86-21-62489820 \\ Fax: +86-21-62489821
}


(C) 2012 The Author(s). Licensee IntechOpen. This is an open access article distributed under the terms of the Creative Commons Attribution 3.0 License, which permits unrestricted use, distribution, and reproduction in any medium, provided the original work is properly cited. 